\title{
Metachromatic leucodystrophy in three families from Nova Scotia, Canada: a recurring mutation in the arylsulphatase A gene
}

Marion B Coulter-Mackie, Liane Gagnier, M Jill Beis, Derek A Applegarth, David E C Cole, Kevin Gordon, Mark D Ludman

\section{Department of Pediatrics, University of British Columbia, Vancouver, British Columbia, Canada M B Coulter-Mackie L Gagnier \\ D A Applegarth}

Department of Pathology and Laboratory Medicine, University of British Columbia, Vancouver, British Columbia, Canada M B Coulter-Mackie D A Applegarth

Atlantic Research Centre, Dalhousie University, Halifax, Nova Scotia, Canada $M \mathrm{~J}$ Beis

M D Ludman

Biochemical Diseases Laboratory, BC Children's Hospital, Vancouver, British Columbia, Canada D A Applegarth

Department of Clinical Biochemistry, Banting Institute, Toronto, Ontario, Canada

D E C Cole

Department of Pediatric Neurology, Izaak Walton Killam Hospital for Children, Halifax, Nova Scotia, Canada

K Gordon

Correspondence to: Dr Coulter-Mackie, British Columbia's Children's Hospital, Room 2F22, 4480 Oak Street, Vancouver, British Columbia, Canada V6H 3V4.

Received 25 September 1996 Revised version accepted for publication 10 December 1996
Abstract

Metachromatic leucodystrophy (MLD) is a lysosomal storage disease resulting from a deficiency of arylsulphatase $A$. We have identified a child with infantile onset MLD who is homozygous for an A212V mutation, a mutation previously reported but not further characterised. We have introduced this mutation into an arylsulphatase $A$ expression vector by site directed mutagenesis. Transient expression of this mutant plasmid in COS cells yields very low levels of arylsulphatase $A$ activity consistent with the patient's phenotype. The arylsulphatase $A$ pseudodeficiency also segregates in this family causing difficulty in interpreting enzyme levels in the absence of DNA data. Two other patients from the same province, also carrying the $A 212 \mathrm{~V}$ allele, have juvenile and adult onset MLD and are heterozygous for P426L ("A" allele) and I179S alleles respectively, known late onset alleles.

$(\mathcal{M}$ Med Genet 1997;34:493-498)

Keywords: metachromatic leucodystrophy; lysosomal storage disease; arylsulphatase A

Metachromatic leucodystrophy (MLD) is a neurodegenerative lysosomal storage disease resulting from a deficiency of activity of arylsulphatase A (EC 3.1.6.1), an enzyme involved in the normal catabolism of cerebroside sulphatide. ${ }^{1}$ A characteristic feature of MLD is the accumulation of cerebroside sulphatide particularly in myelin forming cells of the CNS.

The arylsulphatase $\mathrm{A}$ gene is a small gene whose sequence and structure are well documented. $^{2}$ A number of mutations have been identified in this gene. ${ }^{3}$ Among these are two common alleles, the "I" (IVS2+1) and "A" (P426L) alleles, ${ }^{4}$ associated with infantile and later onset MLD respectively. These two alleles together account for $54 \%$ of MLD alleles. There is also a pseudodeficiency associated with arylsulphatase $A$ in which enzyme levels are significantly reduced without any clinical or biochemical evidence of disease. ${ }^{5}$ The pseudodeficiency allele (Pd) occurs at $10-20 \%$ in the general population. This $\mathrm{Pd}$ allele consists of a complex of two mutations, a glycosylation site mutation (N350S) in exon 6 affecting the third glycosylation site of the enzyme, and an $A \rightarrow G$ in the first poly A addition signal ${ }^{6}$ (AATAAC $\rightarrow$ AGTAAC). The glycosylation site mutation apparently has little effect on enzyme activity whereas the poly A site mutation reduces arylsulphatase $\mathrm{A}$ by up to $80 \%$.

Although the arylsulphatase A gene has a few common mutations which occur in a significant proportion of cases, there are also a large number of mutations which recur to a limited extent or are private. Identification of such mutations has limited diagnostic usefulness beyond particular families or ethnic groups, although it may provide useful information for population genetics studies. Knowledge of these mutations can, however, sometimes provide valuable clues to functional domains within the enzyme and will be of interest later in correlations with phenotype and with structural analyses of the protein.

We describe here three unrelated families from the Nova Scotia province of Canada in whom a missense mutation in exon 3 causes a A212V alteration. This mutation was previously reported in a family of British origin, ${ }^{7}$ but no expression studies were reported nor did the mutation recur among 40 normal chromosomes and $32 \mathrm{MLD}$ chromosomes in that study. In the Nova Scotia families, the phenotypes are infantile, juvenile, or adult onset depending on the other allele present.

\section{Materials and methods}

PATIENTS

Patient 1 (family 1) was born to consanguineous parents of predominantly Acadian background and was noted at about $2 \frac{1 / 2}{2}$ years to have difficulties with gait. She was clinically assessed at the age of 3 years and tested for arylsulphatase A because of a family history of MLD. Her fibroblast arylsulphatase A level (table 1) was consistent with infantile onset MLD. She deteriorated rapidly in her third year, developing seizures and losing speech, walking ability, and head control. At the age of 4 she was no longer able to sit, had swallowing problems, and had no reflexes in her legs. At $41 / 2$ she was unresponsive to pain and required tube feeding. She died at the age of 4 years 8 months. The pedigree for family 1 is shown in fig 1 where the proband is VII.3. This pedigree represents a highly consanguineous kindred extended through seven generations.

Patient 2 (family 2), of French or Acadian and British background, was well until about the age of 10 when he began tripping and was 
Table 1 Arylsulphatase $A$ activity in extracts of patient leucocytes or fibroblasts

\begin{tabular}{llllll}
\hline & & & \multicolumn{3}{c}{ Control $^{*}$} \\
\cline { 5 - 6 } Family & Cell type & Aryl $A^{*}$ & Average & Range \\
\hline 1 & Patient & Fibroblast & 0.303 & 37.9 & $22.3-49.6$ \\
& Father & Fibroblast & 17.07 & 37.9 & $22.3-49.6$ \\
& Aunt VI.16 & Leucocyte & 0.2 & 10.6 & $4.1-17.1$ \\
& Uncle VI.17 & Leucocyte & 4.2 & 10.6 & $4.1-17.1$ \\
& Cousin VI.13 & Leucocyte & 6.2 & 9.8 & $4.7-14.8$ \\
2 & Patient & Fibroblast & 0 & 37.9 & $22.3-49.6$ \\
& Mother & Leucocyte & 6.4 & 7.9 & $2.8-17.9$ \\
& Father & Leucocyte & 10.3 & 7.9 & $2.8-17.9$ \\
& Normal sister & Leucocyte & 16.1 & 7.9 & $2.8-17.9$ \\
& Patient & Fibroblast & 32.8 & 211 & $106-264$ \\
& Sister & Leucocyte & 8.7 & 118.5 & $55-182$ \\
& Mother & Leucocyte & 1.7 & 118.5 & $55-182$ \\
& Father & Leucocyte & 20.3 & 118.5 & $55-182$ \\
& Leucocyte & 27.8 & 118.5 & $55-182$ \\
\hline
\end{tabular}

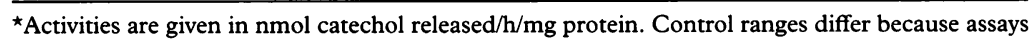
were performed at different times and in different laboratories.

Patients 1 and 2 were assayed as described in Materials and methods.

Patient 3 and family were assayed according to Baum et al. ${ }^{10}$

slow to respond to questions. He was found to have an intention tremor and early signs of spasticity. Neuropsychological studies showed impaired memory but preservation of intellect. CT and MRI scans showed diffuse demyelination. Measurement of arylsulphatase A (table 1) in the patient (cultured fibroblasts) and his parents (leucocytes) were consistent with juvenile onset MLD.

Patient 3 (family 3), of British and Dutch background, was diagnosed with adult onset MLD and has been previously described. ${ }^{8} \mathrm{At}$ about the age of 40 he displayed progressive confusion and lack of concentration. Psychiatric evaluations had suggested schizophrenia or severe personality disturbance. Assessment as possible early onset Alzheimer's disease was inconclusive, although CT scan showed white matter changes consistent with a demyelinating disease. At the age of 47 , following further deterioration in social behaviour, he was screened for metabolic disorders. A deficiency of arylsulphatase $\mathrm{A}$ was identified in both white cells and cultured fibroblasts (table 1). His older sister, also assessed for Alzheimer's disease, similarly showed a deficiency of arylsulphatase $\mathrm{A}$.

These studies were approved by the University of British Columbia Clinical Screening Committee for Research Involving Human Subjects and the BC Children's Hospital In Hospital Research Review Committee.

\section{MATERIALS}

ID Pol, a heat stable DNA polymerase from Thermus flavus, was purchased from ID Labs Inc (London, Ontario). Restriction enzymes were obtained from New England BioLabs (Mississauga, Ontario) or BoehingerMannheim Canada (Laval, Quebec). ${ }^{35}$ S-dATP for sequencing and Sequenase (USB) kits were obtained from Amersham Canada Ltd (Oakville, Ontario). Kits for site directed mutagenesis (Unique Site Elimination), as well as the expression vector pSVL, were obtained from Pharmacia Canada (Baie d'Urfe, Quebec). The TA cloning kit was purchased from Invitrogen (San Diego, California). The pHEXB43 cDNA clone was obtained from the ATCC (Rockville, MD). A cloned cDNA copy of the arylsulphatase $A$ gene was kindly provided by Dr V Gieselmann (Germany).

DETERMINATION OF ARYLSULPHATASE A ACTIVITY IN CELL EXTRACTS

Fibroblast cultures were grown under standard conditions and harvested at about $75 \%$ confluence for assay. Cells were homogenised and cell free supernatants were used in assays with a p-nitrocatechol sulphate substrate in an assay specific for arylsulphatase $\mathrm{A}^{9}$ modified from Baum et al. ${ }^{10}$ Extracts from transfected COS cells were prepared and assayed in the same way. The COS cell extracts were diluted until a linear response to volume added was obtained.

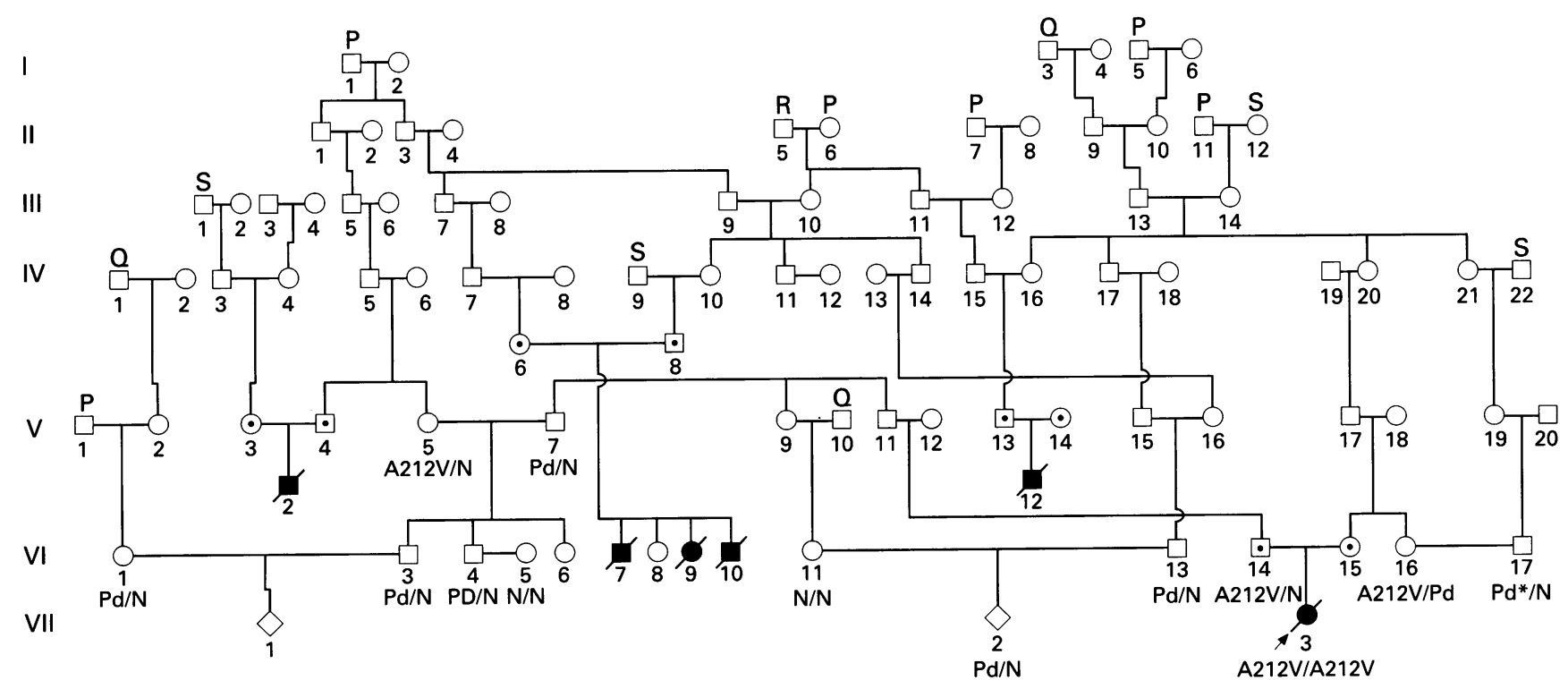

Figure 1 Pedigree of family 1, the infantile onset MLD patient's family. The proband is VII.3. P, $Q, R$, and $S$ indicate entry points of four major family lines involved in this pedigree. Symbols with dots indicate obligate heterozygotes. Filled symbols indicate MLD affected subjects. A diamond indicates a fetus. Alleles are indicated for those people whose DNA was tested. $N$ indicates a normal sequence at the sites tested, Pd, a pseudodeficiency allele, A212V, fetus. Alleles are indicated for those people whose DNA was tested. Nition site mutation of the Pd allele was present. This pedigree, as shown, dates back to the early 19 th century. The P family had settled in the area more than 50 years earlier. It is unknown how many MLD affected subjects were born into this family before generation VI when presumably the disease would not have been diagnosed. 
Table 2 Sequences of oligonucleotides used in PCR amplifications

\begin{tabular}{lll}
\hline Sequence (5'-3') & Nucleotide number (5'-3') \\
\hline & & \\
1 & cgggcgaagcTTCCTCATTCGTACCACAGG & $2816-2797$ \\
2 & gctcgaatCTGCTGGAGCCAAGTAGCCCT & $-56--36$ \\
3 & cgcggaattCTTGATGGCGAACTGAGTGAC & $1671-1691$ \\
4 & cgcgtctaGAACGCTCTGCAAAGCTCTGCC & $1062-1041$ \\
5 & gctaaagCTTGCCCTGTGCACAGAATTGGC & $2275-2297$ \\
6 & ctatGGCCAATCTGTGCACAGGGCAAG & $2298-2275$ \\
7 & atatgatTCGGCCACGGTCACCTCCTCCA & $476-454$ \\
8 & gagaggatCCAGTGCTAACTCCAGTCTTTG & $987-1008$ \\
9 & cgtggaattCAGTCACTCAGTTCGCCATCAAG & $1693-1671$ \\
10 & cacagaatTCAGGGACTCTGTGACTTGTC & $341-361$ \\
15 & ATCAGGGCTTCCATCGATTCTAG & $562-585$ \\
20 & CTTGGACAGGTCATAGAGC“T”GC & $2403-2382$ \\
23 & AGAAGCGGTGCACGTCCAG & $1991-2009$ \\
\hline
\end{tabular}

Nucleotide numbers refer to the genomic sequence in GenBank (X52150) where position 1 is the first base of exon 1. Lower case letters indicate residues not present in the genomic template sequence and are not numbered. The underlined bases represent restriction enzyme recognition sequences which were introduced to facilitate cloning. "T" (primer 20) represents a mismatch inserted into the sequence to create a PstI site when the " $\mathrm{A}$ " allele mutation is present.
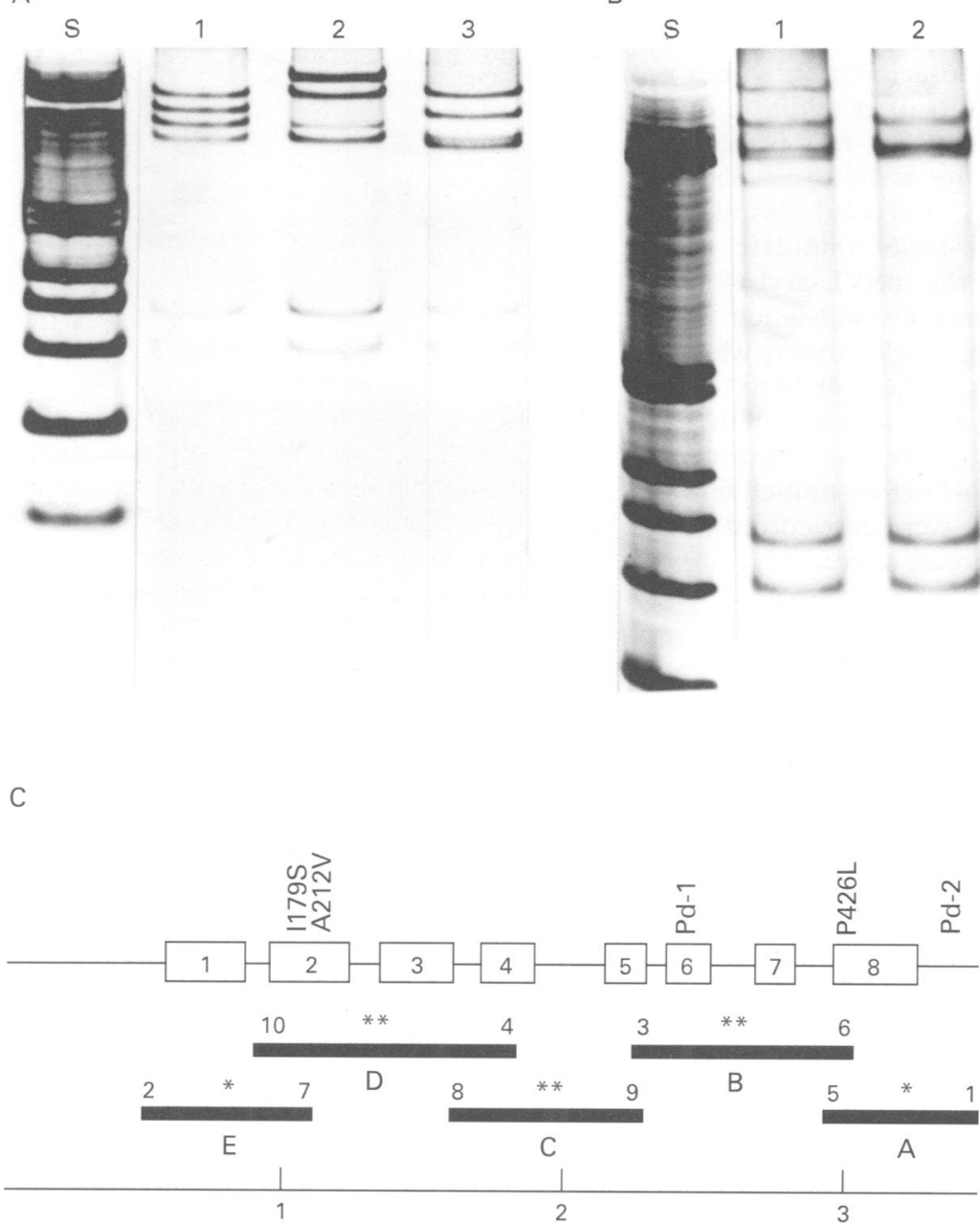

$\mathrm{kb}$

Figure 2 SSCP analysis of segment $D$. (A) patient 1, A212V homozygote, and $(B)$ patient 3, A212V/I179S heterozygote. In both cases, the PCR product was digested with ApaI and analysed as described in Materials and methods. The results shown are for a gel run at $20^{\circ} \mathrm{C}$ without glycerol. S indicates a lane with a pBR322/HinfI size marker. Panel $A$ shows a control sample in lane 1, the homozygous A212V/A212 V proband in lane 2 and an unrelated homozygous "I" allele (IVS2+1) sample in lane 3 for comparison. Panel $B$ shows the A212V/I179S heterozygous sample in lane 1 and a control sample in lane 2. In both $A$ and $B$ the bands of interest are in the top quarter of the gel. Double stranded bands are in the lower half and correspond to the appropriate bands in the size marker lanes. (C) PCR amplified segments used for SSCP analysis. Exons 1-8 and the intervening and non-coding sequence is shown approximately to scale. Segments $A-E$ amplified for PCR are indicated by black bars with numbers designating the primers on the ends. The restriction sites used to generate fragments suitable for PCR are shown as * (segment $A$, SmaI; B, HinfI; C, HindIII/PstI; D, ApaI; E, PvuII). The locations of the pertinent mutations are shown above the gene. $P d-1$ and $P d-2$ represent the two mutations associated with pseudodeficiency.
POLYMERASE CHAIN REACTION (PCR)

AMPLIFICATION

The oligonucleotide primers used in PCR reactions are listed in table 2 . PCR amplifications were performed using standard procedures ${ }^{11}$ using DNA extracted either from cultured fibroblasts or leucocytes. Primers were added to a final concentration of $1 \mu \mathrm{mol} / 1$ each. Substrate DNA was added at $1 \mu \mathrm{g} / 100 \mu \mathrm{l}$. ID Pol polymerase was used at $0.75-1.25$ units $/ 100 \mu \mathrm{l} . \mathrm{MgCl}_{2}$ concentration was at 1.5 $\mathrm{mmol} / \mathrm{l}$ unless otherwise stated. Cycling parameters were: denaturation at $94^{\circ} \mathrm{C}$ for two minutes, annealing at 60 or $65^{\circ} \mathrm{C}$ as indicated for 1.5 minutes, extension at $72^{\circ} \mathrm{C}$ for two minutes for 30 cycles followed by a seven minute extension at $72^{\circ} \mathrm{C}$. All reaction mixtures were overlaid with mineral oil and amplification initiated by addition of polymerase to a hot $\left(94^{\circ} \mathrm{C}\right)$ reaction mixture.

Genomic DNA was amplified in five overlapping segments for preliminary screening for single strand conformational polymorphisms (SSCP) to detect probable sites of mutations (fig 2C). The following primer combinations and annealing temperatures were used: segment $\mathrm{A}$, primers $5 / 1,60^{\circ} \mathrm{C}$; segment $\mathrm{B}$, primers $3 / 6,65^{\circ} \mathrm{C}$; segment $\mathrm{C}$, primers $8 / 9,60^{\circ} \mathrm{C}$; segment $\mathrm{D}, 10 / 4,65^{\circ} \mathrm{C}$; segment $\mathrm{E}, 2 / 7,65^{\circ} \mathrm{C}$.

PCR amplification followed by restriction enzyme digestion was used to test for the $\mathrm{Pd}$ allele, the "I" allele, the "A" (P426L) adult onset allele, and the A212V mutation. Primers and restriction enzymes for $\mathrm{Pd}$ and "I" alleles have already been described. ${ }^{9}$ Primers 15 and 4 (annealing temperature $65^{\circ} \mathrm{C}$ ) were used to test for the A212V mutation. A new site for AatII (GACGTC) is created by the mutation. Primers 20 and 23 (annealing temperature $65^{\circ} \mathrm{C}$ ) were used to test for the P426L allele. A new site for PstI (CTGCAG) is created by the mutation in conjunction with the mismatched base in primer 20 .

SINGLE STRAND CONFORMATIONAL

POLYMORPHISM (SSCP)

PCR segments A-E were screened for alterations affecting the mobility of single strands by a modification of a previously described method. ${ }^{12}$ PCR segments were initially digested with restriction enzymes to generate fragments smaller than 300 base pairs appropriate for analysis (A, SmaI; B, HinfI: C, HindIII/PstI; D, ApaI; E, PvuII). Approximate locations for primers and restriction sites are shown in fig $2 \mathrm{C}$. The samples were analysed under four sets of gel and temperature conditions $\left( \pm 10 \%\right.$ glycerol, $20^{\circ} \mathrm{C}$ or $4^{\circ} \mathrm{C}$ ) using a $2.5 \%$ cross linked gel to optimise sensitivity. ${ }^{13}$ Control and patient samples were matched for known polymorphisms in the segment. Results were visualised by silver staining.

SEQUENCING

Dideoxy sequencing was performed on PCR products after purification with PCRapids ${ }^{\text {TM }}$ (ID Labs) or after cloning into a pCRII vector for TA cloning. Sequencing products were labelled with ${ }^{35} \mathrm{~S}$-dATP and visualised by autoradiography. All nucleotide numbering is based 
on the genomic DNA sequence in GenBank X52150 unless otherwise specified. Nucleotide 1 is the first coding nucleotide of the sequence which is position 630 in X52150. This follows the pattern of mutation position numbering used in a recent review. ${ }^{3}$

SITE DIRECTED MUTAGENESIS

An expression vector, pSVL-arylA, was created by inserting a full length arylsulphatase $A$ cDNA into the pSVL vector. The A212V mutation was generated directly in the expression plasmids using a kit based on the "unique site elimination" method. ${ }^{14}$ Plasmids were purified with QIAGEN (Studio City, California) columns and the sequence confirmed before use.

\section{TRANSFECTIONS}

Transient expression studies were performed using the normal and mutant pSVL-arylA expression vectors. The vector was introduced into COS cells by $\mathrm{CaPO} 4$ precipitation with a $20 \%$ DMSO shock six hours after addition of DNA. ${ }^{15}$ Cells were harvested for protein determination ${ }^{16}$ and enzyme assay three days after addition of the DNA. A second plasmid, (pHEXB43) coding for $\beta$-hexosaminidase $B$, was cotransfected with the pSVL-arylA in order to provide a control for efficiency of transfection and expression. Cell extracts were assayed for total $\beta$-hexosaminidase activity (A plus B) by standard methods ${ }^{17}$ using a 4 -methyl umbelliferyl- $\beta-\mathrm{N}$-acetylglucosamide substrate and measuring release of 4-methyl umbelliferone (4MU). Transfections were carried out in duplicate and repeated at least once.

\section{Results}

PRELIMINARY SCREENING FOR COMMON MUTATIONS

DNA samples from leucocytes or cultured fibroblasts from the three probands were initially screened for the common " $I$ " and " $A$ " alleles and Pd mutations by PCR amplification and restriction enzyme digestion. With this screen, patient 2 was found to be a heterozygous carrier of the "A" allele, P426L (data not shown).

\section{SSCP ANALYSIS}

Segments A-E of the arylsulphatase A gene were amplified from each of the probands and subjected to SSCP analysis as outlined in Materials and methods. Both patients 1 and 3 showed alterations in segment $\mathrm{D}$, as shown in fig 2. This segment became the focus of subsequent sequencing studies.

\section{SEQUENCE ANALYSIS}

Sequencing of segment $\mathrm{D}$ in patient 1 indicated that she was homozygous for a $C \rightarrow T$ transition at position 898 of the gene in exon 3 which would generate an $\mathrm{A} 212 \mathrm{~V}$ alteration (fig 3A). This mutation has previously been identified in a heterozygous state in one patient of British origin. ${ }^{7}$ The mutation creates a new restriction site for the enzyme AatII. Use of this enzyme confirmed that the mutation was homozygous in this patient (fig 3B).

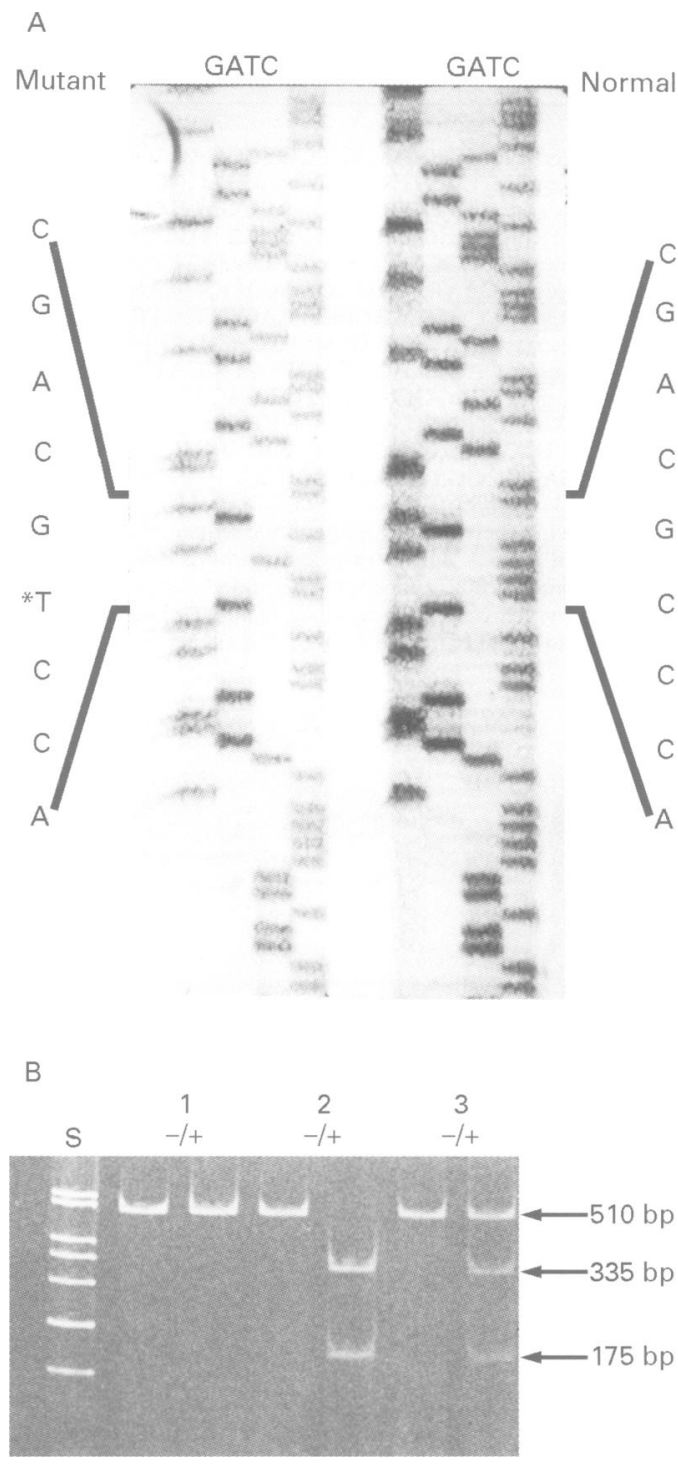

Figure 3 (A) Sequence analysis of A212V mutation. Cloned PCR product showing the A212V mutation

(C898T) is shown on the left and normal sequence on the right. (B) AatII digestion of PCR product with A212V mutation. The A212V mutation creates a new AatII site such that the $510 \mathrm{bp} P C R$ product is cut to $335 \mathrm{bp}$ and 175 bp fragments. Samples are shown -1+ AatII. Sample 1, control; sample 2, A212V homozygote, the proband from family 1 (VII.3 in fig 1); sample $3, A 212$ V heterozygote, the father of the proband (VI.14 in fig 1$)$. DNA standards ( $p B R 322 /$ HinfI) are shown on the left.

The AatII digestion was also used for PCR products from patients 2 and 3 and showed that each of them was heterozygous for the A212V mutation (data not shown). Where DNA was available, family members were also tested, The results for family 1 are noted in the pedigree in fig 1 . In family 2 , the $\mathrm{A} 212 \mathrm{~V}$ mutation was inherited through the mother who was of French or Acadian descent and was inherited by two of six sibs (data not shown). Subsequent sequence analysis of segment $D$ in patient 3 identified a second mutation in exon 3. This mutation, a $T \rightarrow G$ at position 799 , would cause an I179S amino acid alteration. This mutation has previously been described ${ }^{18}$ in an adult onset patient of Swiss origin. In summary, the infantile onset MLD was associated with $\mathrm{A} 212 \mathrm{~V} / \mathrm{A} 212 \mathrm{~V}$, the juvenile with $\mathrm{A} 212 \mathrm{~V} / \mathrm{P} 426 \mathrm{~L}$, and the adult onset with A212V/I179S. The locations of these muta- 
tions within the arylsulphatase $\mathrm{A}$ gene are shown in fig $2 \mathrm{C}$.

SITE DIRECTED MUTAGENESIS AND TRANSIENT EXPRESSION STUDIES

Expression studies were performed to confirm that the $\mathrm{A} 212 \mathrm{~V}$ mutation did indeed have the potential to cause late infantile MLD seen in patient 1 where it is homozygous. The mutation was introduced into the pSVL-arylA vector by unique site elimination. COS cells were cotransfected with the normal pSVLarylA or the A212V mutant and the pHEXB43 plasmid as a control for the transfection efficiency and expression capability of the cells. The total $\beta$-hexosaminidase activity generated in each case was 22.8 and $32.1 \times 10^{3} \mathrm{nmol} 4$ $\mathrm{MU}$ released $/ \mathrm{h} / \mathrm{mg}$ protein respectively for the normal and mutant pSVL, combinations indicating that there was comparable or better transfection efficiency for the mutant plasmid case and that the cells were fully competent to express cDNAs for lysosomal enzymes. The range of arylsulphatase A activity generated with the normal pSVL-arylA plasmid was 4.83-16.53 $\mathrm{nmol}$ nitrocatechol released $/ \mathrm{h} / \mathrm{mg}$ protein whereas the $\mathrm{A} 212 \mathrm{~V}$ mutant plasmid generated on average $1.1 \%$ as much arylsulphatase A activity as the normal plasmid. This is consistent with the extremely low enzyme activity found in fibroblast extracts from patient 1 (table 1).

ARYLSULPHATASE A PSEUDODEFICIENCY IN RELATIVES OF PATIENT 1

Patient 1 came from a highly consanguineous family (fig 1) with a strong Acadian background. Because of the family history of MLD, several family members had been tested enzymatically to determine carrier status. Specifically, subjects VI.13, 16, and 17 had shown low normal or below normal arylsulphatase A activities and were considered possible MLD carriers. DNA testing for the $\mathrm{A} 212 \mathrm{~V}$ and the $\mathrm{Pd}$ mutations in these and other family members indicated that the Pd allele was also segregating in this family (fig 1 ) and had resulted in errors in previous carrier designations based on enzyme activity alone. Subject VI.16 had shown a very low arylsulphatase A activity (table 1) and was shown to carry both the $\mathrm{A} 212 \mathrm{~V}$ and the Pd alleles.

\section{Discussion}

We have identified a mutation which is present in three families from Nova Scotia, Canada. This mutation, a C898T missense alteration in exon 3 of the arylsulphatase A gene, would result in substitution of valine for alanine at amino acid 212. The $\mathrm{A} 212 \mathrm{~V}$ mutation was found in a homozygous state in one family and a heterozygous state with a $P 426 \mathrm{~L}$ and an I179S mutation in the other two families.

The A212V mutation has been previously reported in one instance in a patient of British origin. ${ }^{7}$ In that case, the mutation was heterozygous with an A224V in an adult onset MLD patient. Expression studies for these mutations were not reported so the severity of the mutation could not be accurately determined.
We have found the $\mathrm{A} 212 \mathrm{~V}$ mutation now in three patients, one of whom, an infantile onset case, is homozygous. We have also completed transient expression studies in heterologous COS cells. The alanine at position 212 is not conserved among the various sulphatase ${ }^{1}$ and the $\mathrm{A} 212 \mathrm{~V}$ is a relatively minor alteration between two non-polar amino acids. However, the mutation virtually eliminates production of arylsulphatase A activity from the transfected plasmid. Although we do not know at what level the mutation exerts its effect, for instance, processing, substrate binding, etc, the effects of such a mutation on enzyme activity would be consistent with the extremely low enzyme activity found in fibroblast extracts from the homozygous, affected child and her severe early onset course. The results of the expression studies and the infantile onset of the disease in the homozygous affected child clearly indicate that this mutation causes a severe phenotype. The second mutations (P426L and I179S) found in the juvenile and adult onset patients respectively are known to be associated with somewhat milder forms of disease $^{418}$ and are consistent with the phenotypes in these patients.

DNA testing of family members for the A212V mutation as well as other common mutations indicated that the $\mathrm{Pd}$ allele was also segregating in this family. In several cases, the presence of the $\mathrm{Pd}$ allele had resulted in people mistakenly designated as MLD carriers when assessment was based on arylsulphatase $\mathrm{A}$ activity alone. For such family members, genotyping has altered their apparent risk of producing a child with MLD.

The " $A$ " allele mutation, P426L, has been calculated to occur in approximately $30 \%$ of MLD genes. The I179S mutation has a calculated frequency of $2 \% .{ }^{1}$ Until now recurrence of the $\mathrm{A} 212 \mathrm{~V}$ has not been reported. We have found the $\mathrm{A} 212 \mathrm{~V}$ mutation in three families with homozygosity in only one. In that case the kindred is highly consanguineous and a single allele from a common ancestor is the most likely explanation. In family 1 , the subjects confirmed to have the $\mathrm{A} 212 \mathrm{~V}$ mutation are direct descendants of I.1, I.5, and II.6 (fig 1), all of whom are cousins within family 1-P. Although we have not established a genealogical connection between families 1 and 2 , the mother in family 2, the carrier of the $\mathrm{A} 212 \mathrm{~V}$, also has French or Acadian heritage. Family 3 has a mixed western European background. Recurrence of the $\mathrm{A} 212 \mathrm{~V}$ allele is therefore unlikely to be the result of a recent founder effect, as has been observed for other disorders in specific Nova Scotian demes, including the prevalence of Fabry disease in Acadian Nova Scotians $^{19}$ and the clustering of neonatal hyperparathyroidism in south western Nova Scotians of British origin. ${ }^{20}$ For pseudo-vitamin D deficient rickets, linkage disequilibrium mapping of flanking polymorphic markers provides a genetic confirmation of the hypothesis that the prevalence of this recessive disorder in Acadians of Nova Scotia and the other Maritime Canadian provinces is the result of a 
founder effect that dates back to the earliest generations of Acadian settlement. ${ }^{21}$

The original A212V mutation in the arylsulphatase A gene was reported in a person of British background, ${ }^{7}$ while British, Dutch, and French or Acadian origins are claimed by the three families reported here. Family 1-P had been settled in the Nova Scotia area before the British takeover in 1763 . We suggest that the A212V mutation is likely to predate the founding settlements of Maritime Canada (16041800), but identification and mapping of flanking markers should allow for linkage disequilibrium analysis that could strengthen this hypothesis and yield a preliminary estimate of the date of origin

This work was supported by a grant from the British Columbia Health Research Foundation. We are indebted to Ms Jennifer Toone (Biochemical Diseases Laboratory, Vancouver) and Dr Rip (Department of Biochemistry, University of Wester R (Department of Biochemistry Ontario and CPRI, London, Ontario) for performing arylsulphat Mackie (Department of Biochemistry and Molecular Biology University of British Columbia) and $\mathrm{Dr}$ B A Gordo and CPRI, London, Ontario) for helpful discussions.

1 Kolodny EH, Fluharty AL. Metachromatic leukodystrophy and multiple sulfatase deficiency: sulfatide lipidosis. In: and multiple sulfatase deficiency: sulfatide lipidosis. In Scriver CR, Beaudet AL, Sly WS, et al, eds. The metabolic and molecular bases of inherited disease.

2 Kreysing J, Gieselmann V. Structure of the arylsulfatase A gene. Eur ₹ Biochem 1990;191:627-31.

3 Gieselmann V, Zlotogora J, Harris A, Wenger DA, Morri CP. Molecular genetics of metachromatic leukodystrophy. Hum Mutat 1994;4:233-42.

4 Polten A, Fluharty AL, Fluharty CB, Kappler J, von Figur $\mathrm{K}$, Gieselmann V. Molecular basis of different forms of metachromatic leukodystrophy. N Engl f Med 1991;324: 18-22.

5 Thomas GH. "Pseudodeficiencies" of lysosomal hydrolases. Am $\mathcal{F}$ Hum Genet 1994;54:934-40.

6 Gieselmann V, Polten A, Kreysing J, von Figura K. Arylsulfatase A pseudodeficiency: loss of a polyadenylation signal and N-glycosylation site. Proc Natl Acad Sci USA 1989;86: a436-40.
7 Barth ML, Fensom A, Harris A. Missense mutations in the arylsulphatase $\mathrm{A}$ genes of metachromatic leukodystrophy patients. Hum Mol Genet 1993;2:2117-21.

8 Sadovnick AD, Tuokko H, Applegarth DA, Toone JR, Hadjistavropoulos T, Beattie BL. The differential diagnosis of adult onset metachromatic leukodystrophy and early onset familial Alzheimer disease in an Alzheimer clinic population. Can F Neurol Sci 1993;20:312-18.

9 Coulter-Mackie MB, Rip J, Ludman MD, Beis J, Cole DEC Metachromatic leucodystrophy (MLD) in a patient with a constitutional ring chromosome 22. 7 Med Genet with a constitution.

10 Baum H, Dodgson KS, Spencer B. The assay of arylsulfatases A and B in human urine. Clin Chim Acta 1959;4:453-

11 Innis MA, Gelfand DH, Sninsky JJ, White TJ, eds. $P C R$ protocols. A guide to methods and applications. 1st ed. San Diego: Academic Press, 1990.

12 Ainsworth PJ, Coulter-Mackie MB. A double mutation in exon 6 of the $\beta$-hexosaminidase $\alpha$ subunit in a patient with the B1 variant of Tay-Sachs disease. Am $\mathcal{f}$ Hum Genet 1992;51:802-9.

13 Hayashi K, Yandell DW. How sensitive is PCR-SSCP? Hum Mutat 1993;2:338-46.

14 Deng WP, Nickoloff JA. Site-directed mutagenesis of virtually any plasmid by eliminating a unique site. Anal Biochem 1992;200:81-8

15 Sambrook J, Fritsch EF, Maniatis T, eds. Molecular cloning. a laboratory manual. 2nd ed. Cold Spring Harbor, New York: Cold Spring Harbor Laboratory Press, 1989.

16 Lowry OH, Rosebrough NJ, Farr AL, Randall RJ. Protein measurement with the folin phenol reagent. 7 Biol Chem 1951;193:265-75.

17 Lowden JA. Evidence for a hybrid hexosaminidase isoenzyme in heterozygotes for Sandhoff disease. $\mathrm{Am} \mathcal{F ~ H u m}$ Genet 1979;31:281-9.

18 Fluharty AL, Fluharty CB, Bohne W, von Figura K, Gieselmann V. Two new arylsulfatase A (ARSA) mutations in a juvenile metachromatic leukodystrophy (MLD) patient. Am f Hum Genet 1991;49:1340-50.

19 Kirkilionis AJ, Riddell DC, Spence MW, Fenwick RG. Fabry disease in a large Nova Scotia kindred: carrier detection using leucocyte $\alpha$-galactosidase activity and an $N c o l$ polymorphism detected by an $\alpha$-galactosidase cDNA clone. F Med Genet 1991;28:232-40.

20 Janicic N, Pausova Z, Cole DEC, Hendy GN. Insertion of an Alu sequence in the $\mathrm{Ca}^{2+}$-sensing receptor gene in familial hypocalciuric hypercalcemia and neonatal severe familial hypocalciuric hypercalcemia and neonatal sever

21 Labuda M, Labuda D, Korab-Laskowska M, et al. Linkage disequilibrium mapping in young populations: pseudovitamin D deficiency rickets (PDDR) in French Canadians. Am f Hum Genet 1996;59:633-43. 